\title{
A DILEMMA FOR BUDDHIST REDUCTIONISM
}

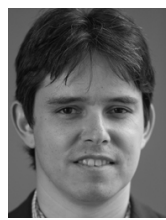

\section{Javier Hidalgo}

Jepson School of Leadership Studies, University of Richmond

hidalgoj@gmail.com

\section{Introduction}

Buddhists accept the doctrine of non-self. Almost all Buddhists agree that selves or persons are unreal. ${ }^{1}$ Instead, the term "person" is merely a way of referring to a causal series of psychophysical elements. Nonetheless, Buddhists also claim that persons are real in a different sense. Persons are conventionally real. So, Buddhist philosophers deny the ultimate reality of persons and affirm their conventional existence.

How is it possible for persons to exist and yet not exist? Buddhist Reductionism is an answer to this question. Buddhist Reductionism gives an analysis of what it means for persons to lack ultimate existence and retain conventional existence. Buddhist Reductionists claim that persons don't belong in our final ontology. So, it is false that persons ultimately exist. But persons are conventionally real in the sense that positing the existence of persons is useful. If we accept that persons are real, this will help us to achieve desirable outcomes, such as the minimization of suffering. Furthermore, Buddhist Reductionists extend their analysis to all composite entities, not just persons. They defend a kind of mereological nihilism according to which all partite entities are unreal. Buddhist Reductionists contend that the only real existents are particular bundles of tropes, such as color and shape. In recent years, Mark Siderits and other philosophers have developed important and powerful arguments in favor of Buddhist Reductionism. ${ }^{2}$

In this article, I will raise an objection to Buddhist Reductionism. My objection centers on the nature of reasons. It seems obvious that there are reasons, such as reasons for action and reasons for belief. Yet I will show that Buddhist Reductionists are unable to account adequately for the existence of reasons. More precisely, I will argue that Buddhist Reductionists face a dilemma. They can understand reasons either as composite or impartite properties. If reasons are composite, then it is false that reasons exist. And, if it is false that reasons exist, then Buddhist Reductionism entails that there are no reasons for action or belief, including reasons to believe Buddhist Reductionism. Alternatively, Buddhist Reductionists can view reasons as impartite properties. If reasons are impartite, then reasons must be irreducible normative properties. But the existence of irreducible normative properties is incompatible with other important Buddhist commitments, such as the causal efficacy 
criterion of ultimate reality, nominalism about abstract objects, and perhaps dependent origination. So, on one horn of the dilemma Buddhist Reductionism has unacceptable consequences, and on the other horn Buddhist Reductionism conflicts with key Buddhist tenants.

I will proceed as follows. Section 2 will clarify Buddhist Reductionism. Section 3 will lay out the dilemma for Buddhist Reductionism. I will then consider objections to my arguments. One objection holds that, even if reasons lack ultimate existence, reasons may be still be conventional truths. Another objection is that there is a viable alternative understanding of value in the Abhidharma tradition that may escape the dilemma that I pose for Buddhist Reductionism. I will rebut these objections in section 4. Section 5 concludes the article.

\section{Buddhist Reductionism}

My presentation and subsequent critique of Buddhist Reductionism will focus primarily on Mark Siderits' reconstruction and defense of this view, although I will also draw on other philosophers who endorse components of Buddhist Reductionism. ${ }^{3}$ According to Siderits, Buddhist Reductionism has four major components. First, Buddhist Reductionism advances a theory of truth. According to this theory, there are two truths-conventional and ultimate truths. Some statements are conventionally true because they are useful, and some statements are ultimately true because they describe what reality is like. Second, Buddhist Reductionism endorses mereological nihilism. Mereological nihilism says that anything that we can reduce to constituents lacks ultimate existence. So, all composite entities are ultimately unreal. Third, Buddhist Reductionists advance a specific ontology. They believe that the only irreducible entities are bundles of tropes, such as shape and mass. Finally, Buddhist Reductionists advance a distinctive kind of consequentialist ethics. I will now elaborate on these commitments.

Buddhist philosophers draw a distinction between ultimate and conventional truths, and Buddhist Reductionists offer a distinctive analysis of these truths. Here is their definition of conventional truth: a statement is conventionally true if and only if the acceptance of this statement reliably leads to successful practice. ${ }^{4}$ Consider the claim "the sterilization of surgical instruments prevents infection in patients." This sentence is conventionally true because it helps us to avoid suffering. If we-and surgeons in particularaccept this statement, then surgeons will sterilize their instruments before surgery, and this will cause fewer patients to suffer as the result of infections. Thus, this statement leads to successful practice.

The definition of ultimate truth is: a statement is ultimately true if and only if it both corresponds to the facts and neither asserts nor presupposes the existence of what is not ultimately real. ${ }^{5}$ Statements are ultimately true if they accurately describe what reality is really like. Suppose for the sake of 
illustration that string theory describes the fundamental structure of reality. If so, then everything is composed of one-dimensional vibrating strings. Statements about these strings can be ultimately true. After all, if infinitesimal strings are the deepest nature of reality, then statements about these strings may correspond to the facts and refrain from asserting the existence of things that are unreal.

The second major feature of Buddhist Reductionism is mereological nihilism. Mereological nihilism says that only impartite entities are ultimately real, and that composite entities are unreal. So, anything that we can reduce to more fundamental constituents doesn't exist. For example, cars are composite entities. Cars are composed of engines, fuel tanks, wheels, and so on. So, it is false that cars belong in our final ontology because they are partite. Cars lack reality above and beyond the individual parts that make them up.

Buddhists extend mereological nihilism to persons. Persons are composed of mental and physical states, such as bodies, consciousness, and mental formations. If persons are composite entities, it follows that persons lack existence from the perspective of ultimate reality. The dialogue Milinda Pañha is an influential statement of this view. In this dialogue with the IndoGreek king of Bactria, the Buddhist monk Nāgasena denies that he exists. He says that "Nāgasena' exists as a mere designation. However, in the ultimate sense there is no person as such that is found." ${ }^{6}$ Nāgasena's reasoning is that he is a partite entity composed of material form and mental states and thus cannot exist. Nāgasena's argument depends on the view that composite entities are unreal.

But why should we accept mereological nihilism? Buddhist Reductionists offer different arguments for this position. One of the most influential is the neither-identical-nor-distinct argument. The argument goes like this. If wholes exist, then either wholes are identical with their parts or distinct from them. To take Nāgasena's example, if a chariot exists as a whole, then it is either identical with the components that make it up (the spokes, wheels, etc.) or distinct from these components. It is impossible for the whole and the parts to be identical because they have different properties. The parts are many and the whole is one. Assuming the indiscernibility of identicals, the parts and the whole can't be identical. Is the whole distinct from its parts? This seems false because the whole gains all of its causal powers from the parts. If the whole gains all of its causal powers from the parts, then we can explain the whole entirely in terms of its parts. Entities that can be entirely explained in terms of facts about their constituent parts are not distinct from their parts. Therefore, the whole is neither identical with nor distinct from its parts. We can conclude that wholes don't exist.

There are other arguments for mereological nihilism, but they're not important to my argument in this article and so I will put them to one side for now. Let's move on to the final major component of Buddhist 
Reductionism: Abhidharma metaphysics. Buddhists in the Abhidharma tradition hold that the fundamental constituents of reality are dharmas. According to one plausible interpretation, dharmas are tropes. ${ }^{7}$ Tropes are features of particular entities. Tropes are things like the color, shape, or texture of an object. Tropes aren't universals. Rather, they are properties that are located in a particular place and time. What we call "universals" are just aggregations of particular tropes or dharmas. According to many Abhidharma philosophers, dharmas are also momentary. While dharmas exist for a time, they rapidly disappear. Finally, dharmas are impartite and simple. We are unable to reduce them to more fundamental properties. So, Abhidharma philosophers think that objects are composed of bundles of impartite dharmas. When combined with mereological nihilism, the upshot is that the world we know is illusory. Reality in fact consists in an ever changing succession of dharmas.

Furthermore, Buddhist Reductionism accepts a causal criterion of existence. According to Siderits' reconstruction, Buddhist Reductionists believe that only entities that have causal properties can exist. One of the most influential formulations of the causal efficacy criterion is Dharmakīrti's claim that "whatever has the capacity for causal efficacy is ultimately existent; everything else is just conventionally existent." ${ }^{8}$ Siderits affirms this causal efficacy criterion. Siderits says that "Buddhist Reductionism... relies on the causal efficacy criterion for real entities" and that "the panBuddhist position [is] that causal efficacy is the mark of the ultimately real." ${ }^{9}$ If the causal efficacy criterion is correct, then properties must have causal powers in order to be ultimately real.

Now that I've sketched out some of the main contours of Buddhist Reductionism, let's return to the Buddhist analysis of persons. Remember that Buddhist Reductionists believe that persons are ultimately unreal and conventionally existent. I have already explained why Buddhist Reductionists deny that persons exist: persons are composite entities and therefore can't be real from an ultimate perspective. But Buddhist Reductionists say that persons are conventionally real. Why? Buddhist Reductionists think that accepting that persons exist is useful. In particular, accepting that there are persons minimizes suffering better than other possible conventions. So, statements about persons can be conventionally true because positing the existence of persons promotes good consequences.

Siderits gives the following illustration. ${ }^{10}$ We teach children to care about their futures, even when they're disinclined to care. For example, we try to get our children to brush their teeth, eat their vegetables, and study for their next spelling test, despite the fact that they find all of these activities to be unpleasant. In doing this, we encourage children to identify with their pasts and futures and conceive of themselves as enduring entities with prudential interests. This habituation is useful because it reduces pain on net. There will be fewer toothaches if children brush their teeth. More 
generally, there will be less suffering if we identify with our futures and seek to avoid painful outcomes. In this respect, the personhood convention is helpful.

Here's another illustration, again from Siderits. ${ }^{11}$ If persons lack reality, then no one can deserve anything. Desert seems to be a property that only persons could possess. After all, you and I don't deserve anything if we don't exist. Nonetheless, it's a good thing that judges treat murderers as if they were deserving of punishment. This is so because punishing murderers reduces suffering overall by deterring future murders. Thus, treating murderers as if they were persons promotes utility and helps explain why the personhood convention is justified.

Siderits contends that we should adopt the personhood convention because this minimizes suffering overall. But why should we aim to minimize suffering overall? Here Siderits and other Buddhist Reductionists invoke Sāntideva's argument in Bodhisattvacaryāvatāra. ${ }^{12}$ Sāntideva says that a person is an aggregate of psychophysical constituents, similar to how an army is an aggregate of soldiers. Along with Buddhists in the Abhidharma tradition, Sāntideva suggests that aggregates are unreal. Since persons are aggregates of psychophysical constituents, they're unreal as well. If persons are unreal, it is false that we should only minimize our own suffering. We should reduce suffering irrespective of its location.

We can break down this interpretation of Sāntideva's argument as follows:

1. There are reasons to minimize suffering in my own life.

2. Persons ultimately don't exist.

3. If there are reasons to minimize suffering in my own life and persons ultimately don't exist, then there are reasons to minimize suffering irrespective of the location of this suffering.

4. So, there are reasons to minimize suffering irrespective of its location.

Premise 1 holds that we should reduce our own suffering. Everyone agrees that we should prevent our own suffering. Moreover, Sāntideva suggests that we are rationally required to minimize suffering on net. He writes: "All doctors use painful treatments to restore health. It follows that to put an end to many sufferings, a slight one must be endured."13 By the same logic, we should minimize sufferings on balance within our lives.

Premise 2 is an affirmation of the Buddhist doctrine of non-self, which I have already discussed. Premise 3 is the conditional claim that, if there are reasons to minimize suffering in my own life and persons ultimately don't exist, then there are reasons to minimize suffering irrespective of the location of this suffering. The motivation for this premise is that we lack grounds for prioritizing the reduction of our own suffering if persons are unreal. If persons are unreal, then the fact that suffering is yours and not mine is 
irrelevant because ultimately there is no such thing yours and mine. There are just pains, and, if pains are to be minimized, then they must be minimized regardless of where they occur.

Siderits and other authors like Charles Goodman who are sympathetic to Buddhist Reductionism endorse this argument for minimizing suffering. This argument supports a kind of Buddhist consequentialism. Siderits remarks: "welfare is constituted by purely impersonal states and events, and that it is these that ought to be considered in determining what to do." ${ }^{14}$ This consequentialist moral theory justifies the personhood convention. We ought to reduce suffering overall. According to Siderits, the best way to reduce suffering overall is to conceive of ourselves to be persons. For sure, Siderits maintains that we should deviate from the personhood convention when this would produce superior impersonal outcomes. But, for the most part, it's a good thing for us to think of ourselves as persons.

This completes my description of Buddhist Reductionism. I will now develop an objection to it

\section{The Dilemma}

My objection to Buddhist Reductionism centers on the nature of reasons. Reasons are considerations that count in favor of A doing X. We think that we have reasons for action, reasons for belief, reasons for attitudes, and so on. For example, you might think:

(i) The fact that some action would promote your survival is a reason to do it.

(ii) The fact that some statement is true is a reason to believe it.

(iii) The fact that someone is altruistic is a reason to admire this person. ${ }^{15}$

Claims (i)-(iii) seem plausible. Buddhist Reductionists also agree that there are reasons. In particular, they claim:

(iv) The fact that some action would minimize suffering on net is a reason to do it.

But can Buddhist Reductionists make sense of reasons? How do reasons fit into Buddhist ontology?.

Buddhist Reductionists have two ways of understanding the nature of reasons: either (a) reasons are composite or (b) these reasons are irreducible and impartite. Either option leads us into trouble. If we assume (a), then it turns out that reasons are unreal. If we opt for (b), then Buddhist Reductionism contradicts fundamental Buddhist commitments. So, both options for Buddhist Reductionism have unacceptable implications. Let me now explain the horns of this dilemma in detail. 


\section{A. Reasons are Composites}

Let's start with the first option, the position that reasons are composites. How can reasons be composites?.

A Humean analysis of reasons illustrates how it is possible for reasons to be composites. ${ }^{16}$ This account holds that psychological states, such as desires, explain reasons. More specifically, a Humean theory of reasons relies on the idea of constitutive explanations. Consider an analogy. A triangle is a composite entity. A triangle is constituted by three lines arranged in a certain way. The arrangements of lines explains what it is for something to be a triangle. Something is a triangle because it has three sides. Similarly, a Humean theory of reasons holds that reasons are constituted by psychological states. To have a reason to perform some action just is to have a psychological state that disposes you to perform this action under the right conditions.

Here's an illustration. Suppose that Sam has a reason to go to a party at his friend's house. ${ }^{17}$ The explanation for this reason is that Sam has a desire to go to the party if he thinks it will be fun. Sam believes that the party tonight will be fun. Thus, he has a reason to go to the party. Sam's desires and beliefs about the party just are what it is for Sam to have a reason to attend the party. Sam's psychological states are constitutive of his reasons. Consider also our reasons to reduce suffering. A Humean might say that our reasons to minimize suffering are constituted by our psychological disposition to avoid suffering under certain circumstances. In this way, we can decompose reasons into more fundamental constituents-a person's psychological states. A Humean theory is a reductive theory of reasons: it says that we can reduce reasons to non-normative properties.

Notice that reasons are partite in the Humean account. Reasons have constituents: psychological states. However, Buddhist Reductionism is committed to mereological nihilism. Mereological nihilism says that there are no composite or partite entities. It is false that there are chariots. There are only a collection of wheels, spokes, carriages, and other components that we group together for our own purposes. The only things that exist are simple and impartite dharmas. Mereological nihilism is crucial to Buddhist Reductionism because it underwrites the rejection of selves and persons. As persons are partite, they lack existence. Yet, if mereological nihilism is a claim about the metaphysical status of all composite entities, then it should apply to reasons, too. So, if composite entities are unreal and reasons are composite, then reasons are unreal. Reasons are mere conceptual constructions.

The unreality of reasons raises serious problems for Buddhist Reductionism. If reasons don't exist, then Buddhist Reductionists may need to jettison their ethical commitments. Buddhist Reductionism depends on the view that there are reasons to reduce suffering. But, if there are no reasons, then there are no reasons to minimize suffering or bring about other good outcomes. 
Buddhist Reductionists believe that persons are conventionally real because the personhood convention brings about desirable outcomes. Yet, without reasons to bring about good outcomes, there is no reason to affirm the reality of persons. The result is that Buddhist Reductionism collapses into eliminativism about persons, the view that persons are entirely unreal.

Many philosophers think that the Humean analysis of reasons applies to reasons for action. Sam has a reason to go the party because he has a desire to do so. Yet some philosophers believe that we can give all reasons a Humean analysis, including epistemic reasons for belief. Sharon Street holds this view. ${ }^{18}$ She thinks that epistemic reasons depend on our attitudes. We have reasons to believe true propositions only because we have practical reasons to engage in the "belief business." The belief business is the project of determining whether our beliefs are true or false. So, our epistemic reasons depend on our practical reasons. For example, we have reason to believe the truth about whether there's a tiger in the bush next to us because we have a reason to avoid being eaten. Our practical reasons, like our reason to escape being eaten, are the reasons to form true beliefs about tigers. But Street argues that our practical reasons are dependent on our attitudes. Practical reasons are constructed out of, or constituted by, these attitudes. If epistemic reasons depend on practical reasons and practical reasons are attitude-dependent, then epistemic reasons are attitude-dependent as well.

Suppose that Street is right that epistemic reasons depend on, or are constructed out of, psychological states. Thus, if mereological nihilism is true, then there are no reasons for belief, as reasons for belief are constituted by attitudes. If there are no reasons-including epistemic reasons-then we lack reasons to believe Buddhist Reductionism. This seems like a problematic result. Consider an analogy. Suppose that I made the following two claims:

(1) It is definitely raining outside.

(2) I have absolutely no reason at all to believe that it is raining outside.

There's something wrong with the conjunction of these two statements. The problem is that (2) undermines any reason to endorse (1). Similarly, my argument suggests that Buddhist Reductionists are committed to the conjunction of the following claims:

(3) Buddhist Reductionism is true.

(4) There is no reason to believe Buddhist Reductionism.

Claim (4) undermines our reasons for believing (3). Buddhist Reductionism entails that we lack any reason believe it. In this respect, Buddhist Reductionism seems self-defeating. ${ }^{19}$ 
Maybe Buddhist Reductionists can somehow avoid global skepticism about reasons. Some error theorists about normativity try to drive a wedge between normative reasons and epistemic reasons. These error theorists deny that epistemic reasons are normative. Instead, reasons for belief are merely descriptive statements. ${ }^{20}$ Suppose that these error theorists are right. Perhaps we can then restrict skepticism about normativity to reasons for action and exempt reasons for belief. That would still be bad news for Buddhist Reductionists. This skepticism would undercut the ethical component of Buddhist Reductionism and the conventional existence of persons. So, if we consider reasons to be composites, then Buddhist Reductionists must jettison at least some of their core commitments. ${ }^{21}$

\section{B. Reasons are Impartite}

Let us now consider the other horn of the dilemma. Recall that there are two options for Buddhist Reductionists: they can believe that reasons are composite or impartite. Now let us consider the second option, the view that reasons are impartite. If reasons are impartite, then they are irreducible. We can't decompose reasons into more fundamental constituents. Why? Buddhist Reductionists say that anything that is reducible to some other properties must be composite in nature. And anything that is impartite is irreducible. It follows, then, that impartite reasons are irreducible properties. Reasons are among the fundamental constituents of the world, along with tropes like color, mass, and shape.

This understanding of reasons has something in common with contemporary non-naturalism about reasons. Derek Parfit, Thomas Scanlon, and other philosophers contend that reasons are irreducible normative truths. ${ }^{22}$ Consider the claim that there are reasons to minimize suffering. Nonnaturalists would say that these reasons are irreducible. The reasons to minimize suffering are not identical with or reducible to non-normative statements, such as the fact that I have a desire to avoid suffering. It is also false that reasons are constructed out of, or constituted by, other properties. Rather, reasons are sui generis normative properties. Scanlon puts the point as follows:

$[T]$ ruths about reasons are fundamental in the sense that truths about reasons are not reducible to or identifiable with non-normative truths, such as truths about the natural world of physical objects, causes and effects, nor can they be explained in terms of notions of rationality or rational agency that are not themselves claims about reasons. ${ }^{23}$

Non-naturalism about reasons and the view that reasons are impartite share the implication that reasons are irreducible properties. So, if we think that reasons are impartite, then, surprisingly, it seems that Buddhist Reductionists must be committed to something like non-naturalism about reasons. 
Here's a problem though: it is unclear whether the view that reasons are irreducible normative properties is consistent with other Buddhist commitments. The issue is that if reasons are irreducible normative properties then it seems false that they have causal powers. The claim that irreducible normative properties lack causal efficacy is the standard view among contemporary non-naturalists. Parfit writes: "[w] hen some fact gives us a reason to have some belief, this normative property of being reason-giving is not an empirically discoverable feature of the natural world. Nor could we be causally affected by such normative properties." ${ }^{24}$ David Enoch contends that basic "normative truths are causally inert." 25 Scanlon, Thomas Nagel, and other non-naturalists agree that irreducible normative properties don't have causal powers. ${ }^{26}$.

Why should we believe that irreducible normative properties lack causal efficacy? To motivate this commitment, notice that reductionist theories of reason are unable to justify the view that normative truths are independent of our attitudes and judgments. Consider ideally coherent malevolence. Let's imagine a person who has the sole aim of maximizing the suffering of others. And assume that this malevolent person is entirely coherent. Even if this evildoer had full information and his beliefs and attitudes were completely consistent, he would desire to inflict suffering on others. Does this evildoer have normative reason to maximize suffering? If our normative reasons are a function of our attitudes or desires, then this evildoer seems to have decisive normative reason to inflict suffering. This result is counterintuitive to many of us. Yet non-naturalists can say that the coherent evildoer is making a mistake. They can claim that, irrespective of what your desires and attitudes are like, the stance-independent truth is that you don't have normative reasons to maximize the suffering of others. ${ }^{27}$.

We can now see one reason why non-naturalists are led to conclude that normative properties lack casual powers. If natural properties were causally or constitutively responsible for normative truths, then normative truths would depend on the natural ones, like an agent's attitudes, desires, or judgments. And these commitments rule out the stance-independence of normative truths. Non-naturalists have other reasons for rejecting the causal efficacy of normative properties as well. Non-naturalists argue that we are unable to reduce the meaning of normative claims to statements about causally efficacious natural properties. ${ }^{28}$ In their view, the claim that "I have a normative reason in favor of performing action $X^{\prime \prime}$ contains information that is absent in the claim that "I have a desire to perform action X" or other similar claims about natural properties in the world. Non-naturalists contend that natural and normative properties are simply too different for naturalistic analyses of normative properties to be successful.

Let's suppose that contemporary non-naturalists are right that irreducible normative properties lack causal powers. This implies that Buddhist Reductionism and non-naturalism about normativity are incompatible. Recall 
that Siderits accepts a causal efficacy criterion of existence. A causal efficacy criterion of existence holds that only properties or entities that have causal powers are part of ultimate reality. A range of other Buddhist philosophers endorses this view as well. For example, in explaining why Buddhists reject the existence of universals, Jay Garfield remarks: "Since universals are abstracta, and hence both causally inert and permanent, they fail to satisfy the most fundamental Buddhist criteria for reality-causal interdependence and spatio-temporal locality." ${ }^{29}$ This causal efficacy criterion seems compatible with a reductionist account of reasons. If reasons were reducible to desires and attitudes, then they would be part of the causal fabric of the universe. After all, desires and attitudes are part of the causal nexus. But are irreducible normative properties consistent with the causal efficacy criterion? It looks like the answer to this question is "no." Only properties with causal powers belong in our final ontology. Yet irreducible normative properties lack causal efficacy. Thus, if irreducible normative properties are real, then the causal efficacy criterion is false.

You might think that a Buddhist Reductionist should jettison the causal efficacy criterion, especially if the alternative is to deny the existence of reasons altogether. The problem is that if Buddhist Reductionists affirm the existence of irreducible normative reasons, this also puts pressure on other, related Buddhist commitments. For example, the causal efficacy criterion appears to be conceptually related to the doctrine of dependent origination. One prominent interpretation of dependent origination is that everything has a casual explanation and, moreover, that all entities are subject to origination, duration, and cessation. ${ }^{30}$ All entities are impermanent and caught in a chain of causation, and there is no reality above and beyond the causal web. This interpretation of dependent origination suggests that all that exists has a causal backstory. If so, then dependent origination and the causal efficacy criterion are similar or perhaps even equivalent ideas.

Most Buddhist philosophers are also nominalists. They deny the existence of universals in part because universals are causally impotent. Universals are eternal and unchanging entities. Eternal and unchanging objects lack the power to produce causal effects at particular times. If the criterion that distinguishes what is real from what is merely conventional is causal efficacy, then universals are unreal. But, if irreducible normative reasons exist, then why not universals too? Both are causally inert. Thus, if normative properties are real, then it is hard to see why we should deny the existence of universals and other abstract objects.

Contemporary philosophers often object to non-naturalism about reasons on epistemological grounds. They ask how we could come to acquire knowledge about irreducible normative properties. Ordinarily, we gain knowledge through causal interaction. Imagine that I claim that my dishwasher is broken. How do I know this? Well, I causally interacted with my dishwasher in various ways. Perhaps I tried to start it up, but it didn't work. Or I examined 
it closely and noticed some of the machinery was damaged. Even abstruse scientific knowledge depends on causal interactions. We can understand the properties of black holes and electrons because they affect our environment. ${ }^{31}$ But irreducible normative truths are causally inefficacious. We can't see or touch them. So, how then can we possibly know about them?.

This objection to abstract objects is dependent on the causal theory of knowledge. According to this theory, knowledge requires a causal link between the knower and the object of knowledge. Many Buddhist epistemologists endorse a causal theory of knowledge. For instance, Dharmakîrti claims that we acquire knowledge of the world by causally interacting with it. Dharmakirti says that "that is perceptible which causes the content of awareness to track its own presence and absence. ${ }^{\prime 32}$ Our environment causes perceptual awareness of unique particulars, and this is how we gain knowledge of them. The only other epistemic instrument is inference, and inference is reliable only insofar as it depends on perception. ${ }^{33}$.

This suggests another problem with irreducible normative properties. If Buddhists are committed to a causal theory of knowledge, then it is a mystery how they can make sense of knowledge of reasons. Buddhist epistemology arguably lacks the resources to explain how we can acquire knowledge of normativity. So, if there are irreducible normative reasons and we have knowledge of them, then at least some Buddhists must jettison their theory of knowledge. Alternatively, suppose that Buddhists want to retain their theory of knowledge. Buddhists thus seem committed to epistemic skepticism about reasons. There seems to be no way that we could come to possess knowledge of causally inert properties.

I won't continue belaboring the point. The view that reasons are impartite and irreducible is incompatible with central Buddhist philosophical commitments. If Buddhist Reductionists are committed to the existence of irreducible normative properties, then they must reject these commitments. Perhaps other kinds of reductionists can reply: "so much the worse for Buddhism!" But this response is unavailable to Buddhist Reductionists. At the very least, Buddhist Reductionists have compelling reasons to refrain from claiming that reasons are irreducible.

\section{Summary}

This completes my initial presentation of a dilemma for Buddhist Reductionism. To recap, my argument goes like this:

1. Buddhist Reductionists must accept either that normative reasons are composite or impartite.

2. If reasons are composite, then reasons ultimately do not exist.

3. If reasons ultimately do not exist, then ultimately there are no reasons to reduce suffering, affirm the conventional existence of persons, and (perhaps) believe Buddhist Reductionism. 
4. If reasons are impartite, then the causal efficacy criterion of ultimate existence, nominalism, and other important Buddhist doctrines are false.

5. So, Buddhist Reductionists must either (a) accept that ultimately there are no reasons to reduce suffering, affirm the conventional existence of persons, and believe Buddhist Reductionism, or (b) conclude that key Buddhist commitments are false.

I will now consider how Buddhist Reductionists might respond to my argument.

\section{Objections and Responses}

A. Are Reasons Conventional?

My argument against Buddhist Reductionism takes the form of a dilemma. If we opt for either of the two options available to Buddhist Reductionists, then we run into trouble. But what if there is a third option? One possible third option is that reasons are conventional. Buddhist Reductionists can claim that, while reasons ultimately don't exist, they have a conventional existence. In a footnote, Siderits suggests this response. He writes: "it could be argued that the notion of a reason for action is unavailable at [the level of ultimate reality] - that reasons are the sorts of things that only persons could be said to have. ${ }^{\prime \prime 34}$ Of course, Siderits denies the reality of persons. So, it seems that he is committed to the conclusion that reasons don't ultimately exist. But Siderits adds that "facts at the ultimate level explain how it comes to be conventionally true that we have reasons for action.".

Siderits seems to be claiming:

(5) Reasons don't exist at the ultimate level of reality.

(6) Reasons exist conventionally.

Now, what does (6) mean? Remember that Siderits defines conventional truth as follows: "A sentence is said to be conventionally true if and only if it reliably leads to successful practice." Siderits suggests that a statement is conventionally true if the acceptance of this statement helps us to achieve good outcomes, such as the reduction of suffering. Suppose that we adopt this analysis of conventional truth. We can then interpret (6) as equivalent to:

(7) Accepting that there are reasons reliably leads to successful practice.

It is an interesting question why accepting that reasons exist would promote desirable outcomes, but let us suppose for the moment that it would. So, the claim that there are reasons would be conventionally true. ${ }^{35}$. 
But there's a problem with the view that reasons are merely conventional. To see why, consider the conventional existence of persons. Buddhist Reductionists claim that we should accept the personhood convention because doing so reduces suffering. Now, suppose that you ask "why should I minimize suffering?" At first glance, the only viable answer to this question invokes reasons. An answer to this question must give you a good reason to reduce suffering. The content of such reasons can vary. But consider some possibilities. Someone might argue that you have reason to minimize suffering because every rational being desires this outcome. Or perhaps that facilitating this outcome is in your self-interest. Maybe God commands you to alleviate suffering. Or suffering is intrinsically bad and that is a reason to reduce it. We can give other explanations for why you could have reasons to minimize suffering as well.

So, an acceptable answer to the question "why should I minimize suffering?" is that you have good reasons to minimize suffering. Yet we can now ask: "why should I believe the statement 'there is good reason to minimize suffering on net'?" Suppose that the statement "there is good reason to minimize suffering on net" is a conventional truth. If this statement is a conventional truth, then you should accept this statement because doing so would minimize suffering. But notice that we have now gone in a circle. This chain of reasoning is in effect claiming:

(8) You have reasons to minimize suffering on net because accepting that you have reasons to minimize suffering on net would minimize suffering on net.

Something has gone wrong here. What, exactly?.

Consider an analogy. Suppose that I was trying to persuade you to take up tennis. Here's my argument:

(9) You have reasons to play tennis because accepting that you have reasons to play tennis would cause you to play tennis.

This is a bad argument. Why? It begs the question. Claim (9) presupposes that playing tennis is valuable, but it gives no independent reasons why this is so. A better argument for playing tennis would give independent reasons in favor of playing tennis. For example, you might claim that playing tennis is fun, it's good for your health, and so on. Now take (8). Claim (8) also begs the question. It presupposes that reducing suffering is valuable. But (8) fails to provide us with any independent reasons to believe that this is the case.

So, there seems to be something wrong with understanding reasons in terms of conventional truths. Here's my diagnosis of the problem. Conventional truths are instrumental to desirable ends, such as happiness, virtue, or reducing suffering. In other words, conventional truths are instrumentally 
valuable. They help us to achieve our goals. But something that is only instrumentally valuable must be a means to something else that is intrinsically valuable. If that weren't the case, then it would be false that this thing has instrumental value. So, we need some reason to believe that the end that justifies conventional truths is intrinsically valuable. And this reason can't be a conventional truth. If this reason is merely conventional, then it would beg the question in the same way that (8) and (9) beg the question. Another way to put the point is that conventional reasons are only instrumental reasons. For instrumental reasons to have weight, they must depend on intrinsic reasons. Otherwise, there would be an infinite regress of value. Thus, conventional truths must bottom out in intrinsic values or reasons.

Let's return to the question: why should we reduce suffering? To answer this question, we must give reasons why should we reduce suffering, and these reasons must, at some point, be intrinsic reasons, reasons why it is in itself valuable to reduce suffering. Notice that, to avoid begging the question, these reasons why reducing suffering is valuable can't be conventional because conventional reasons are instrumental. The only remaining possibility is that these reasons are ultimate reasons, reasons that exist from the perspective of ultimate reality. However, if conventional truths rest on ultimate reasons, then Buddhist Reductionists are unable to escape the dilemma that I have laid out. They must still give an analysis of ultimate reasons. If these reasons are partite, then they lack ultimate existence. And, if they are impartite, then they conflict with core Buddhist commitments.

Let me summarize where the dialectic stands. If truths about reasons were conventional, then Buddhist Reductionists could accept that there are no reasons from the perspective of ultimate truth. So, they could embrace the first horn of the dilemma. Yet Buddhist Reductionists could argue that we still have conventional reasons for action. They could then claim that we can understand their account in terms of conventional reasons. This would mitigate the damage from conceding that there are ultimately no reasons. According to this view, although there are no ultimate reasons, we have conventional reasons to minimize suffering and conventional reasons to affirm the existence of persons. I have shown that this path is unavailable to Buddhist Reductionists. We can't understand reasons in terms of conventional truths in a non-question-begging way. As a result, the dilemma for Buddhist Reductionism remains intact. ${ }^{36}$

B. Help from Abhidharma Metaphysics?

In this subsection, I want to consider the possibility that there is an alternative understanding of value in the Buddhist tradition that can avoid the dilemma that I have set out. This understanding comes from the Abhidharma tradition. As I noted in section 2, Abhidharma metaphysics holds that ultimate reality consists in dharmas, which we might describe as 
tropes. Some of these dharmas are mental factors and include elements like greed, hatred, joy, and compassion. Abhidharma philosophers claim that mental dharmas have normative valences. Certain mental dharmas are good or wholesome (kusala), while other dharmas are bad or unwholesome (akusala), and still others are neutral (abyākata). Mental dharmas are good or bad by virtue of the fact that their ultimate valences are good or bad, and not because we judge them to be so. In addition, facts about the valence of dharmas are ultimate truths rather than conventional ones. Thus, Abhidharma treats goodness and badness as fundamental constituents of reality.

The Abhidharma philosophers seem to have thought that the normative valence of a dharma is not distinct from the dharma itself. Rather, to experience the dharma fully and clearly just is to see it as wholesome, neutral, or unwholesome. Unwholesome dharmas such as anger and hatred produce disturbances in the mind and aversive reactions. In contrast, wholesome dharmas like compassion and loving-kindness are calming and bring ease to the mind. By carefully attending to the nature of experience, we can determine the valence of mental dharmas. Perhaps Abhidharma philosophers were proposing a kind of non-inferential normative knowledge. We acquire knowledge of the normative charge of mental dharmas by skillfully experiencing or observing them, which may require meditation practice. ${ }^{37}$.

My dilemma in this article assumes that there are two kinds of theories of normative reasons on offer: reductionist theories and non-naturalist ones. But perhaps Buddhist Reductionists can propose another understanding of value that draws on the Abhidharma tradition, or another version of nonnaturalism or reductionism that avoids the dilemma that I have proposed. Buddhist Reductionism is arguably committed to something like Abhidharma metaphysics, at least according to Siderits' interpretation. So, it is worth examining whether Buddhist Reductionists can rely on Abhidharma metaphysics to formulate a viable alternative to reductionist and non-naturalist theories. If that project succeeds, then the dilemma that I have sketched out is a false one. It turns out that there is another option on the table.

But does the Abhidharma position present a genuine alternative to reductionist and non-naturalist understandings of normativity? This is unclear. To see the difficulty with this suggestion, let's assume along with Abhidharma philosophers that mental dharmas are valenced as good, bad, or neutral. That's not enough to get us normative reasons. We also need an account of how the goodness and badness of mental dharmas link up with, or generate, these reasons. We use the terms "good" and "bad" in different ways, and sometimes these usages don't imply anything about reasons. Suppose I say of the coat that I am wearing: "this is a good coat." When I say this, I just mean that this coat satisfies certain standards, like keeping me warm. By itself, this meaning fails to imply any commitments about the reasons that I have. At first glance, the same point could apply to dharmas. 
Even if we grant that some dharmas are fundamentally good or bad, we need to say more to specify what this implies for the reasons that we have with respect to these dharmas.

To bridge the gap between goodness and badness and normative reasons, we need to use the terms "good" and "bad" in a reason-implying sense. When we say that something is good or bad in a reason-implying sense, we mean that there are facts about this thing's nature that give us reasons to respond to this thing in a certain way. ${ }^{38}$ Suppose that you believe that happiness is good and pain is bad in a reason-implying sense. If so, you likely believe that you have reasons to bring about more happiness in your life and reasons to minimize the amount of pain in it. Let us assume that mental dharmas are good or bad in a reason-implying sense. The fact that a dharma is wholesome is presumably a reason to bring about similar dharmas in the future or the fact that a dharma is bad is a reason to prevent similar mental dharmas from arising.

But then we need to ask: what is the nature of the reasons to bring about good dharmas or prevent bad or unwholesome ones? We must now furnish an account of these normative reasons. Consider pain as an illustration. Most people agree that we have reason to reduce pain. Why, though? Some non-naturalists say that we have reasons to reduce pain irrespective of the judgments that an agent has toward her pain. ${ }^{39}$ The reasons to minimize pain are irreducible normative properties. Notice that, according to this view, your attitudes and beliefs toward pain can be mistaken. Suppose you thought, strangely, that you should increase the amount of pain in your life, even though this isn't necessary to achieve any other good. Well, you would be wrong. Furthermore, your reasons to avoid pain would not be caused by your attitudes and judgments because normative truths are independent of your attitudes. But, if we go this route, we run into the same problems that confront any attempt to reconcile Buddhist Reductionism with non-naturalism. We would need to reject the causal efficacy criterion of ultimate existence and other associated commitments.

Yet that is not the only theory of the reason-giving badness of pain on offer. There is an alternative, attitude-dependent theory. ${ }^{40}$ This account says that we have reasons to minimize pain by virtue of the fact that we have some desire to avoid pain or some judgment that counts against experiencing pain. This would be a reductionist account. Our reasons to minimize pain are constructed out of psychological states. Once again, though, we run into the same troubles that beset attempts to marry reductionist accounts of reasons with Buddhist Reductionism. If reasons are composites of nonnormative properties and composite entities are ultimately unreal, then we would have to deny that reasons are ultimately real as well. It seems that we can run through this same exercise with any mental dharmas that Buddhist Reductionists propose. 
So, it is unclear whether Buddhist Reductionists can offer a viable understanding of normativity that escapes the dilemma that I have laid out. Abhidharma metaphysics presents us with a fascinating and suggestive understanding of how normative valences can exist as fundamental constituents of reality. Yet, even if we accept this picture of the world, we must still give an account of our reasons to respond to wholesome or unwholesome dharmas in any particular way. That is where the dilemma I have sketched comes back into play. Unless we can figure out a viable alternative to the reductionist and non-naturalist theories of reasons, the dilemma for Buddhist Reductionists retains its force. And there is some ground for doubting that Abhidharma philosophy provides us with this alternative.

\section{Conclusion}

Can Buddhist philosophy make sense of reasons? In this article, I have examined whether one important Buddhist view-Buddhist Reductionismhas the resources to justify the existence of reasons. My diagnosis is pessimistic. I have argued that Buddhist Reductionism lacks the resources to make sense of reasons and, furthermore, that this failure casts doubt on the plausibility of Buddhist Reductionism as a whole. If my argument here is correct, then Buddhist Reductionists face a stark choice. They must either endorse skepticism about normative reasons or reject key Buddhist commitments. Neither option is appealing. If nothing else, this conclusion suggests that Buddhist philosophers have more work to do in clarifying how reasons fit into their ontologies.

\section{Notes}

1 - The possible exception is the Pudgalavāda school of Buddhist thought, although the exact nature of the Pudgalavāda's understanding of the self remains controversial. For discussion, see James Duerlinger, Indian Buddhist Theories of Persons: Vasubandhu's Refutation of the Theory of a Self (New York: Routledge, 2003).

2 - See Mark Siderits, Personal Identity and Buddhist Philosophy, 2nd edition (Burlington, VT: Routledge, 2016); Mark Siderits, Studies in Buddhist Philosophy, ed. Jan Westerhoff (New York: Oxford University Press, 2016); Mark Siderits, Buddhism as Philosophy: An Introduction (Indianapolis, IN: Hackett Publishing Company, Inc., 2007). However, several other philosophers have defended elements of Buddhist Reductionism. See Graham Priest, "Buddhist Ethics: A Perspective," in A Mirror Is for Reflection: Understanding Buddhist Ethics, ed. Jake Davis (New York: Oxford University Press, 2017), pp. 92-108; Charles Goodman, Consequences of Compassion: An Interpretation and Defense of Buddhist Ethics (New York: Oxford University Press, 2014), 
chapter 5. Of course, these authors draw substantially on the thought of historical Buddhist philosophers as well.

3 - There are many views in the Buddhist tradition that we might reasonably refer to as "Buddhist Reductionism." However, in this article my critical target is mainly Siderits' contemporary reconstruction and defense of Buddhist Reductionism. In particular, I will rely heavily on Siderits, Personal Identity and Buddhist Philosophy. Siderits' attitude toward Buddhist Reductionism is subtle. While Siderits develops a systematic case for Buddhist Reductionism, he ultimately argues in favor of a Madhyamaka interpretation of Buddhist thought. But Siderits also contends that Buddhist Reductionism is, in certain respects, compatible with Madhyamaka philosophy, and that Madhyamaka philosophers must appeal to reductionism in order to defend Buddhist commitments. More precisely, Siderits defends epistemic contextualism, according to which ultimate and conventional truths are relative to contexts of inquiry. So, in certain contexts of inquiry, Buddhist Reductionism does reflect the "ultimate truth." But we should at the same time reject the claim that "there is a final level [of reality] at which the real svabhāvas stand revealed." See Mark Siderits, "Is Everything Connected to Everything Else? What the Gopis Know," in Moonshadows: Conventional Truth in Buddhist Philosophy, ed. The Cowherds (New York: Oxford University Press, 2010), pp. 167-180, at p. 179.

4 - Siderits, Personal Identity and Buddhist Philosophy, p. 16; Siderits, Buddhism as Philosophy, pp. 56-57.

5 - Siderits, Personal Identity and Buddhist Philosophy, p. 16.

6 - N.K.G. Mendis, trans., The Questions of King Milinda (Kandy, Sri Lanka: Buddhist Publication Society, 2007), p. 31.

7 - Charles Goodman, "The Treasury of Metaphysics and the Physical World," Philosophical Quarterly 54, no. 216 (2004): 389-401.

8 - Quoted and translated in Dan Arnold, Brains, Buddhas, and Believing: The Problem of Intentionality in Classical Buddhist and CognitiveScientific Philosophy of Mind (New York: Columbia University Press, 2014), p. 21. I have omitted the Sanskrit parentheticals from this quote.

9 - Siderits, Personal Identity and Buddhist Philosophy, p. 145 and p. 125 n. $\mathrm{s}$.

10 - Siderits, Buddhism as Philosophy, pp. 74-75.

11 - Siderits, Personal Identity and Buddhist Philosophy, p. 55.

12 - Jay Garfield, Stephen Jenkins, and Graham Priest, "The Sāntideva Passage: Bodhisattvacaryāvatāra VIII.90-103," in Moonpaths: Ethics 
and Emptiness (New York: Oxford University Press, 2016), pp. 55-76, at p. 60.

13 - Santideva, The Bodhicaryavatara, ed. Paul Williams, trans. Kate Crosby and Andrew Skilton (New York: Oxford University Press, 2008), p. 69.

14 - Siderits, Personal Identity and Buddhist Philosophy, p. 66.

15 - I borrow some of these examples from Sharon Street, "Does Anything Really Matter or Did We Just Evolve to Think So?" in The Norton Introduction to Philosophy, ed. Gideon Rosen et al. (New York: W. W. Norton \& Company, 2015), pp. 685-692, at p. 688.

16 - Mark Schroeder, Slaves of the Passions (New York: Oxford University Press, 2010), chap. 4.

17 - I have adapted this example from Schroeder, Slaves of the Passions, p. 1.

18 - Sharon Street, "Evolution and the Normativity of Epistemic Reasons," Canadian Journal of Philosophy 39, no. S1 (2009): 213-248.

19 - For a more general description of this problem for skepticism about normative reasons, see Spencer Case, "The Normative Error Theorist Cannot Avoid Self-Defeat," Australasian Journal of Philosophy 98, no. 1 (2020): 1-13. Nonetheless, I concede that some Buddhists may be willing to accept a global error theory, and there are passages in Buddhist scriptures that might support this view. For example, one verse in the Dhammapada says that "an awakened one ... has gone beyond both merit and demerit." One might read this and similar passages to mean that ultimate truth contains no normative properties (thanks to an anonymous reviewer for pointing this out). See The Dhammapada, trans. Acharya Buddharakkhita (Kandy, Sri Lanka: Buddhist Publication Society, 1985), pp. 29-30.

20 - For this line of argument, see Jonas Olson, Moral Error Theory: History, Critique, Defence (New York: Oxford University Press, 2017).

21 - An objector can argue that Buddhist Reductionists should bite the bullet and accept that there are no normative reasons. Yet this objector could deny that this implication is unacceptable. Consider an analogy. Suppose that a Buddhist Reductionist denies the existence of water. After all, water is just a series of momentary tropes. Yet we need water in order to live. Does Buddhist Reductionism therefore entail that we will all die of thirst because water is unreal? Obviously not. The underlying tropes that constitute water can do any work that we want water to do, like quenching thirst. Now, Buddhist Reductionism implies that normative reasons don't exist. But that's no problem. The underlying beliefs and desires that are thought to constitute reasons can do 
any work that we want reasons to do, just as the tropes that make up water can perform the functions that we want from water. However, this analogy between water and reasons is suspect. Even if water is ultimately unreal, it can still quench thirst because the tropes that constitute water continue to have causal properties. It is less clear whether something similar works for reasons. Reasons have a justifying role-they justify beliefs, attitudes, and actions. If reasons don't exist, then I am unsure whether the constituents of reasons, such as desires or attitudes, can continue to play this role. We could say that psychological states caused an agent's actions. But, without reasons, I doubt that we could meaningfully say that these psychological states justify an agent's actions, beliefs, or attitudes. Thomas Nagel argues along similar lines that "[w]e cannot replace practical reasoning by the psychology of our practical reasoning capacity, any more than we can replace mathematical reasoning by the psychology of our mathematical capacity" (I want to thank an anonymous reviewer for raising the objection above). See Nagel, The View From Nowhere, rev. edition (New York: Oxford University Press, 1989), p. 150.

22 - T. M. Scanlon, Being Realistic about Reasons (New York: Oxford University Press, 2016); Derek Parfit, On What Matters, vol. 2 (New York: Oxford University Press, 2011); David Enoch, Taking Morality Seriously: A Defense Of Robust Realism (New York: Oxford University Press, 2013).

23 - Scanlon, Being Realistic about Reasons, p. 2.

24 - Parfit, On What Matters, vol. 2, pp. 496-497.

25 - Enoch, Taking Morality Seriously, p. 159.

26 - Thomas Nagel, The Last Word (Oxford: Oxford University Press, 2001), chap. 6.

27 - Derek Parfit, On What Matters, vol. 1 (New York: Oxford University Press, 2011), pp. 73-82.

28 - Parfit, On What Matters, vol. 2, chaps. 26 and 27.

29 - Jay L. Garfield, Engaging Buddhism: Why It Matters To Philosophy (New York: Oxford University Press, 2015), p. 48.

30 - For this interpretation see ibid., chap. 2.

31 - Gideon Rosen makes this point in "Numbers and Other Immaterial Objects," in The Norton Introduction to Philosophy, ed. Gideon Rosen et al. (New York: W. W. Norton \& Company, 2015), pp. 507-515.

32 - Arnold, Brains, Buddhas, and Believing, p. 45. 
33 - See also Jonathan C. Gold, Paving the Great Way: Vasubandhu's Unifying Buddhist Philosophy (New York: Columbia University Press, 2016). Gold argues that Vasubandhu believes that "anything we wish to say exists must be subject to ... analytical, causal analysis" (p. 187) and that causal interaction "is the only legitimate condition of knowledge" (p. 214).

34 - Siderits, Personal Identity and Buddhist Philosophy, p. 96 n. 15.

35 - Many other commentators also argue that Buddhist ethics exists at the level of conventional truths rather than ultimate ones. See Bronwyn Finnigan and Koji Tanaka, "Ethics for Mādhyamikas," in Moonshadows: Conventional Truth in Buddhist Philosophy, ed. The Cowherds (New York: Oxford University Press, 2010), pp. 221-232.

36 - Perhaps an alternative conception of conventional truth can avoid the problems that I raised in this section. But I am skeptical. In my view, the most plausible understanding of conventional truth is a kind of fictionalism. Conventional truth is a kind of pretense that we use because it helps us to achieve our ends. But we must ultimately ask what reasons we have to accept our fictions. And fictionalism about reasons rules out a coherent or non-question-begging answer to this question. For an analysis of different conceptions of conventional truth, see Mark Siderits, Graham Priest, and Tom Tillemans, "The (Two) Truths about Truth," in Moonshadows, pp. 131-150.

37 - I want to thank two anonymous referees for helping me to formulate the Abhidharma position in this and the prior paragraphs. In describing the Abhidharma view here, I also draw on the analysis of the Abhidharma model of the mind in Monima Chadha and Shaun Nichols, "Self-Conscious Emotions without a Self," Philosophers' Imprint 19, no. 38 (2019). For an example of an Abhidharma analysis of conscious experience as normatively "valenced," see Bhikkhu Bodhi, ed., A Comprehensive Manual of Abhidhamma, Buddhist Publication Society, Sri Lanka edition (Seattle: BPS Pariyatti Editions, 2003), chap. 1.

38 - Parfit, On What Matters, vol. 1.

39 - Nagel, The View From Nowhere, chap. 8.

40 - See Sharon Street, "A Darwinian Dilemma for Realist Theories of Value," Philosophical Studies 127, no. 1 (2006): 109-166, at pp. 144-152. 